\title{
The use of humour by therapists and clients in cognitive therapy
}

\author{
Alberto Dionigi \\ Federazione Nazionale Clowndottori \\ research@,fnc-italia.org
}

\section{Carla Canestrari}

University of Macerata

carla.canestrari@unimc.it

\begin{abstract}
The purpose of this study was to investigate several aspects of humour in cognitive therapy. Eight first therapy sessions were examined and seven examples of humour originating from the therapists or the clients are reported: three represent examples of humour initiated by the client, while four are representative of humour initiated by the therapist. This research focuses on the use of humour in psychotherapy and provides evidence that when the clients initiated humour, the therapists responded in three different ways, namely, by aligning themselves with the client, disaligning themselves, or by using a strategy comprising both alignment and disalignment. Diversely, in cases in which the therapist initiated humour, four different forms of humour were identified (i.e. rhetorical humour, humour relating to a surrealistic meaning, role shifting and humour relating to register). In these cases, the clients always laughed, thereby signaling their support. An analysis of these cases demonstrates that humour is an easily integrated therapeutic tool which may be used to favour positive changes.
\end{abstract}

Keywords: humour, laughter, psychotherapy, cognitive therapy, conversation analysis.

\section{Introduction}

Humour is one of the most effective forms of communication that humans employ, and it is of interest in the case of applied research into mental and physical health (Martin 2007; Dionigi $\&$ Canestrari 2016). The presence of humour in psychotherapy came to the attention of researchers and psychologists quite some time ago and several books have been written on the subject (Fry \& Salameh 1987; Strean 1994). One of the main purposes of psychotherapy is to promote positive changes in clients' emotions, behaviour and cognition. These three areas interact with each other and by altering one of them (e.g. cognition), a modulation can occur in another (e.g. emotion) (Barbosa et al. 2017). In fact, humour is a complex interaction 
involving an individual's physiological response (laughter), emotional response (mirth) and/or cognitive response (understanding) to a humorous stimulus (Sultanoff 2013), but unfortunately it is not generally recognized as a valid tool in professional settings as it is viewed as unprofessional (Dziegielewski et al. 2003). However, there are several reasons why humour is worth investigating in the field of psychotherapy: 1) being able to laugh at him/herself and not take him/herself too seriously can facilitate a client's tolerance to criticism, making it possible for the therapist to expose personality flaws and shortcomings in a non-threatening way (Ellis 1977); 2) by means of humour, it is possible for the therapist and client to establish and maintain a positive therapeutic relationship and facilitate the therapeutic alliance (Nelson 2008); 3) a humorous comment from a therapist can defuse an awkward moment, shifting the conversation and placing it within a "comic frame" (Dziegielewski et al. 2003); and 4) since it facilitates positive alternative thoughts in clients, humour represents a useful tool for decreasing resistance in sessions, resulting in a more relaxed and open conversation (Bordan \& Goldin 1999). Humour may also lead to both short-term and long-term positive effects (Kuhlman 1984). The short-term effects refer to a reduction in emotional tension and an increase in feelings of joy as an immediate consequence of a humorous intervention, while the long-term effects relate to the opportunity humour provides in terms of the development of the therapeutic relationship.

There may also be, however, negative effects. In every relationship, including that which develops between a therapist and a client, humour can represent a double-edged sword: when used appropriately, it may lead to significant positive therapeutic effects, but when used inappropriately or misinterpreted, it can also have detrimental effects on the therapeutic relationship (Meyer 2000). This issue merits further study.

\section{The functions of humour in client-therapist interactions}

Despite the fact that the use of humour is important in psychotherapy, there is a shortage of empirical studies which investigate the presence and functions of humour in therapeutic interactions as most of the existing research is theoretical and anecdotal in nature (Voutilainen \& Peräkylä 2016). The majority of the studies conducted so far show how therapists usually laugh less than their clients and use humour less than their counterparts in other areas of therapy (e.g. Dionigi \& Canestrari 2018; Gupta et al. 2014; Marci et al. 2004). A qualitative investigation of psychotherapeutic interactions between clients and therapists showed that clients appreciate amusing comments during their sessions and those that did not experience humour reported that they had quit as a result of this (Bennett 2003). Humour can be effective in counteracting painful effects: a good counsellor should have a spontaneous playfulness, an appreciation of the ridiculous and the ability to stand off and see themselves as silly and foolish (Mahrer \& Gervaize 1984). Sigmund Freud (1960) focused on the role of humour used by the client both as a coping strategy and as an expression of superiority conveying a form of resistance in order to dissipate their feelings of inferiority (Freud 1960). The use of humour on the part of clients may also convey rebellion and dissatisfaction with life, allowing them to express their real feelings while remaining protected (Allport 1961). Additionally, for clients undergoing therapy, the process of cognitive re-elaboration resulting from a humorous comment enables them to see their situation in a different light, thus acquiring an alternative vision to their own way of reasoning (Lynch 2002) fostered by the insight activated while processing the humour (Bianchi et al. 2017; Canestrari et al. 2014; Canestrari et al. 2018).

In the case of therapists, humour can be used in order to demonstrate the ironic aspects of a situation, thereby helping the clients to experience a sensation of lightheartedness which may temporarily attenuate their feelings of sadness (Corey 2005). A client's laughter signals that a 
positive change has occurred as a result of an emotional transition from pain and anxiety to more pleasant emotions (Vaillant 2000). The results of a study based on transcriptions of consultations with couples during counselling sessions suggest that humour is useful because it disarms clients, breaks down their resistance and allows them to explore contrasting explanations for their situation (Buttny 2001). Moreover, an American study which investigated the use of humour in sessions aimed at systematic desensitization in the treatment of spider phobia (Ventis et al. 2001) found that it constituted an effective technique: in fact, the participants in both the group which was exposed to humour and the group which followed the standard course of treatment showed significant and equally large reductions in their fear of spiders while those in the no-treatment group did not show any significant improvement.

For the abovementioned reasons, we consider that it is important to study in more detail how humour works in psychotherapy in order to ascertain the circumstances in which it is effective. The main aim of this paper is to analyse the presence of humour in a corpus of Cognitive Therapy sessions from the perspective of Conversational Analyses in order to investigate the presence and functions of humour.

\section{Methods}

The data for this study were selected from eight first encounter sessions in which humorous utterances were initiated by the clients or the therapists. The encounters involved two psychotherapists and eight clients who had requested consultations in the mental health clinics in the area where they live. All of the clients and therapists involved signed a release form to give their permission for the audiotapes to be used for research purposes. It was decided to focus on these particular sessions since first encounters follow a standard procedure during which therapists gather information. The clients explain their problems and in this way the therapist can then determine what to focus and work on. Any variables that might affect the occurrence of humour, such as the relationship between the two interlocutors (Provine 2004), were kept as constant as possible. Data were collected in two mental health clinics in Italy and the sessions were conducted by two Italian cognitive psychotherapists who had followed the same training and had been practicing for the same length of time (i.e. 3 years). The recordings that were analysed amounted in total to 6 hours and 26 minutes. Each encounter lasted on average 53 minutes and 37 seconds $(M=3217.29, \mathrm{SD}=574.81$, Range $=2378-3900$ seconds $)$. During these eight encounters, the therapists intervened with humorous comments on 12 occasions $(M=1.50$, Range $=0-4)$ and the clients made humorous comments in 10 instances $(M=1.25$, Range $=0-3)$. We decided to report seven excerpts of talk-in-interaction involving humour (four relating to the therapists and three relating to the clients) since these represent prototypical examples of the whole set of data (Jacobs 1986).

Each transcript was analysed from an interactional point of view in order to identify how the participants set a humorous frame to the conversation in the dialogue and to what purpose. The outcome of this analysis was then reviewed in the light of relevant literature. The nature of the humour in each transcript was assessed in terms of a well-known, widespread incongruity-resolution paradigm known as the General Theory of Verbal Humour (Attardo 1997, 2017). According to this theory, a text is humorous when it is compatible with a shift between two opposing scripts (defined as cognitive structures that provide standard information about routines and activities (Attardo, 1994). Usually this shift is triggered by a punch line or another disjunctive element that results in humour as a result of a change to the initial interpretation (Attardo 1994). We took into consideration instances of interactional humour based on speaker intention, audience interpretation, or both (Hay 2001). In order to distinguish between various different forms of humour (e.g. jokes, puns, hyperbole, irony, 
teasing and wordplay), we concentrated on the support strategies that the speakers deployed to signal understanding and agreement, for example laughing, echoing the other speaker's words, contributing more humour, and displays of heightened involvement (Hay 2001). In the following sections, examples of humorous interactions which occurred in a selection of first encounter Cognitive Therapy sessions are analysed.

\section{Results}

\subsection{The use of humour by clients}

The following excerpts include humour instigated by the clients with examples of three different types of response made by the therapists: alignment (excerpt 1) or disalignment (excerpt 2) with the client or a mixed strategy combining alignment and disalignment (excerpt $3)$.

\subsubsection{Alignment between the client and therapist relating to humour}

The following extract was taken from the first encounter session between a male psychotherapist and a 44-year-old male client who had asked for a consultation at his local mental health service. During the session, the client shows the therapist a medical report issued by a psychiatrist in a different city who had prescribed medication for him. He has also brought an additional report (with a different diagnosis) that he explicitly requested from an independent psychiatrist because he did not trust the doctors working in the National Health System in that city.

\section{Excerpt 1}

$1 \mathrm{~T}$ Però mi diceva: dopo::: [dopo lo ] psichiatra, lei ha

But you told me: after :.: [after the ] psychiatrist, you

$2 \mathrm{C}: \quad$ [dopo questo] [after this ]

$3 \mathrm{~T}$ : richiesto un'altra diagnosi, [perché] perché: non si ritrovava

asked for another diagnosis [because] because: you didn't feel

$4 \mathrm{C}$ : $\quad$ [esatto ]

[exactly]

$5 \quad$ Non mi ritrovavo. N::on completamente nella diagnosi (.) e non

I didn't feel good. N: ot completely about the diagnosis (.) and not

6 completamente nel prospetto curativo che aveva fatto il dottor Bianco=:

completely about the cure that Doctor White was suggesting=:

$7 \mathrm{~T}$ : $\quad$ perché era un approccio farmacologico

because it was a pharmacological approach

$8 \mathrm{C}$ : $\quad$ Sì. Me voleva da' il litio.

Yes. He wanted to give me some lithium.

$\rightarrow 9$ Io ho detto:: il litio lo conserviamo per le batterie della macchina(.)

I said:: let's save lithium for car batteries

$10 \mathrm{~T}$ : [ah ah ah aha ] [hah hah hah hah ]

$11 \mathrm{C}$ : [£per le generazioni ]future£ heh heh heh. Ho detto. Ho detto:: [£for future generat]ions£ heh heh heh. I said. I said::

12 penso, che con un po' di colloqui, io riesca a sciogliere i nodi. I think, that with some encounters, I can untangle the knots. 
In the first part of the conversation, the psychotherapist is gathering information about the diagnosis made by the client's previous psychiatrist (lines 1-4). The client and the therapist both contribute to the conversation up to line 5 when the client explains why he abandoned the previous treatment. He states that he did not feel comfortable with the diagnosis that had been made or with the treatment prescribed by the previous doctor (lines 5-6). The therapist overlaps the client's speech saying "because it was a pharmacological approach" (line 7). The client answers affirmatively and reveals the type of treatment chosen by the previous doctor: "Yes. He wanted to give me some lithium" (line 8). Then, he makes a humorous comment: "I said: let's save lithium for car batteries" (line 9). The therapist laughs (line 10) and in the following conversational turn, the client continues to speak in an amused tone of voice (11: "for future generations") and finally laughs. The client then continues in a serious tone of voice explaining the reason why he decided to change psychotherapist (lines 12).

In this case, the client's comment in line 9 can be seen as humorous because it is based on a semantic ambiguity relating to the word "lithium", that is, he refers to it as an element used in car batteries rather than as a type of medicine. According to the analytical model proposed by Canestrari (2010), an interaction is regarded as humorous by the interlocutors due to the copresence of a Meta-Knowledge Resource (i.e. a meta-communicative signal that places the interaction in a humorous frame) and two Knowledge Resources which are pivotal to the structure of a humorous text, that is, Script Opposition and Logical Mechanism (Raskin 1985; Attardo \& Raskin 1991; Attardo 2017). The humorous intention of the comment is signalled by the use of specific meta-communicative indexes (Forabosco 1994). The signal used by the client in this case is an index which is internal to the structure of the text, namely, saying something which is so clearly absurd and incongruous that the humorous intent is unequivocal (Forabosco 1994). The humorous incongruity can be read in terms of Script Opposition, since there is a juxtaposition of two scripts, namely "additive to cure a person" and "additive necessary for a car", which clearly refer to the opposition "human being versus machine". These signals of humorous intention establish a "non bona fide mode of communication" (Raskin \& Attardo 1994) which is acknowledged by the therapist by means of laughter. The shared laughter which follows (Jefferson 1979) (lines 10 and 11) displays the therapist's alignment with and support for the client's humorous intent (Hay 2001) and represents a cooperative conversational activity (Schegloff 2007). In this excerpt, the client uses derogatory humour with the previous psychiatrist as the target of the joke. He uses this strategy to express his frustration with the diagnosis and to deride the previous psychiatrist. He is probably seeking agreement via captatio benevolentiae.

\subsubsection{Disalignment between the client and therapist relating to humour}

The following extract is taken from an interview conducted by a psychotherapist with a male client, aged 42, who is suffering from Obsessive Compulsive Disorder and has serious difficulties sleeping. In this excerpt, the therapist is investigating the reason why the client has asked for a consultation. The client talks about his current clinical status: the degree of his anxiety has decreased during the previous weeks as he has started taking an antidepressant drug called Prozac which was prescribed by another psychiatrist with whom he had an earlier consultation.

\section{Excerpt 2}

$1 \mathrm{C}$ : $\quad$ Ho deciso(.) di->non ho deciso $<$ (.) penso di avere(.)un un po' di pazienza< I decided (.) to-> I didn't decide <(.) I think I have (.) a little patience < 
2 un po' di calma-ho pigliato delle cose- $>$ si figuri $<$ sono

a feeling of calm - I took some things -> of course $<I$

3 uscito dall'ufficio $>$ dieci minuti prima, dico $<$ (.) faccio con calma(.), left the office $>$ ten minutes earlier, I say <(.) I'll take it easy (.),

4 passeggio ehm: mi rilasso $<$ tranquillo:: $>$ proprio::

have a walk ehm: relax $<$ really calm ::> ::

$5 \mathrm{~T}$ :

$\mathrm{Qu}[$ indi dopo:: ]

So[: then::]

$6 \mathrm{C}$ :

[mi sono $\uparrow$ rilassato $\uparrow]$

[I $\uparrow$ relaxed $\uparrow]$

7 T: Quindi:: quindi, dopo il colloquio con la dottoressa, anche, l'ha tranquillizzata? So:: so, and after the consultation with the doctor, did it reassure you?

$8 \mathrm{C}$ : Uhm:: non subito[ovviamente]

Um :: not immediately [obviously]

$10 \mathrm{~T}$ [non subito] [not immediately]

$\rightarrow 11 \mathrm{C}: \quad$ Eperché c'è stato l'effe-l'onda d'urto, dici(hhh)amo£ hhh eh

fthere was the effe- the shock wave, so to spea(hhh)kf hhh heh

12 La sera stessa: ho avuto:: bisogno sempre: di fare riferimento ai miei vicini di casa.

13 Credo che sia stata l'ultima sera che ho mangiato con loro.

I think it was the last night I ate with them.

$14 \mathrm{~T}$ : Ah, perché non riusciva a mangiare da solo?

Ah, because you could not eat alone?

$15 \mathrm{C}$ : Da solo non riuscivo a mangiare:

I was not able to eat alone:

In the first part of the extract, the client is talking about his habits once he finishes work and he explains that recently he has been feeling better (lines 1-6). In the next conversational turn, the therapist asks the client whether the consultation with the previous doctor had reassured him and, by initiating the turn with "so" (repeated twice), elicits a positive answer. The client anticipates the answer with an interjection and a prolonged sound indicating hesitation, then he says "not immediately" (line 8). The therapist then starts speaking, overlapping the client's conversational turn, repeating "not immediately" while the client is saying "obviously". The answer given by the client represents a dispreferred activity. In fact, the therapist expects an affirmative answer to his question, but a negative answer follows instead. This dispreference is marked by a strategy to play for time (an interjection with a prolonged sound) which precedes the client's negative answer. The distance between the preferred answer and the actual one is stressed in the final part of the client's conversational turn which ends in "obviously". It is usual in cases of a dispreferred activity for the interlocutor to provide a justification or explanation, and thus the conversational turn is more elaborate (Pomerantz 1984; Schegloff 2007). In fact, the client goes on in lines 11 to 13 to provide an alternative description of his sensations after the consultation including an attempt at humour which is signalled by laughter and a jocular tone of voice (11: "£there was the effe- the shock wave, so to spea(hhh)k£ hhh heh"). After this, he continues to explain his after-work habits (lines 12-13). The therapist does not reciprocate the laughter and remains silent.

We can interpret the comment by the client in line 11 as hyperbole, that is, he uses a strong physical phenomenon (a shock wave) in juxtaposition with a psychological phenomenon. The use of a hyperbole is particularly conducive to highly evocative and absurd 
imagery and is often employed to convey humour (Bergen \& Binsted 2003). The humorous comment revolves around the dispreferred answer given by the client and it is accompanied by external meta-communicative indexes (in Forabosco's terms, 1994), namely, a jocular tone of voice and laughter, both of which represent a cue for a difficult moment in the conversation (Haakana 2001). This strategy and the use of external indexes mitigates the disagreement displayed by the client in line 8 and probably softens the emotional value of the theme treated. On the one hand, the therapist's silence after the client has laughed signals disalignment with the client's attempt to be humorous since the preferred response to laughter is generally laughter (Jefferson 1979), but on the other hand, given the therapeutic setting, it also has the function of prompting the client to continue speaking (Pomeroy \& Weatherall 2014), which in fact he does (lines 12-13). Given that, in this case, the client is making fun of himself with regard to a personal problem, the main function of this attempt at humour is to attenuate the gravity of the issue, thereby reducing stress.

\subsubsection{Alignment and disalignment of the therapist after an attempt at humour by the client}

The following extract was taken from a first encounter session between a male psychotherapist and an adult female client who suffers from panic disorder. The therapist is assisting the client to improve her awareness of her condition by explaining the fight-or-flight response. In a similar way to Excerpts 1 and 2, humour is initiated by the client. However, in contrast to the previous excerpts, the therapist displays both alignment and disalignment.

\section{Excerpt 3}

$1 \mathrm{~T}$ :

quando eravamo degli uomini della caverna e dovevamo combattere when we were cavemen and we had to fight

2

${ }^{\circ}$ ad esempio per la vita, se ci trovavamo un animale, di

for example for our lives, if we faced an animal, of

3

determinate, diciamo, dimensioni ${ }^{\circ}$, potevamo avere paura e potevamo certain, let's say, dimensions ${ }^{\circ}$, we might be scared and reagire in maniera automatica attaccando. Se ci troviamo di fronte react automatically by fighting. If we are facing a un orso (.) non ci conviene attaccare e in quel caso, l'altro a bear (.) it's not the best thing for us to attack and in that case, the other meccanismo di difesa è scappare via, quindi fuggire (.5) defense mechanism is to run away, to escape (.5) L'attacco di panico fondamentalmente è una forte manifestazione d'ansia: A panic attack is basically a sudden surge of overwhelming anxiety : $\uparrow$ davanti ad un orso $\uparrow$ $\uparrow$ on encountering a bear $\uparrow$

9 T: $\quad$ No.

No.

$10 \mathrm{C}: \quad$.hh ehe[ehehehheh] .hh heh[hehhehheh]

$11 \mathrm{~T}$ [ahhahhah]

$12 \mathrm{C}$ : $£$ è così?£ [ahhahhah]

$£$ is that so?£

13 T: $\quad$ Però l'orso è dentro la nostra testa. Quindi anche una formica, But the bear is inside our head. So even an ant,

14 in un determinato momento, può diventare un orso. 
at a certain moment, can become a bear.

In the first part of this sequence, the therapist is educating the client by explaining the fight-orflight response, a physiological reaction which occurs in response to a perceived harmful event, an attack or threat to survival (Cannon 1932). As a result of acute stress, the sympathetic nervous system of the body is activated, releasing hormones which result in an increase in heart rate, blood pressure and breathing rate. To explain how a panic attack works on a psychological level, the therapist uses a parallelism with the possible responses elicited by an encounter with a bear (lines 4-5), that is, to fight it or run away. The client does not wait until the therapist reaches the transition relevance point and echoes his words (i.e. 8: "on encountering a bear").

The client's intervention can be interpreted as humorous for several reasons. She echoes an issue previously discussed by giving an opposite meaning to the one provided by the therapist (Hay 2001), thereby triggering a shift between two opposite scripts (i.e. the physical absence of a bear versus physical presence of a bear with the opposition usually being justified by an "as if" type of logic). Specifically, the therapist refers to the word "bear" in a metaphorical and abstract sense (i.e. as a threat), while the client refers to its literal and concrete meaning and she "makes as if to say" (Dynel 2013; Grice 1975) that a panic attack is elicited by an encounter with a real bear. The comment is also ironic due to the fact that when she makes this statement, she pitches her voice higher (Rockwell 2000; Schaffer 1982) and inverts the meaning of the echoed word (Sperber \& Wilson 1981) resulting in a contrast between the two meanings of the same word (for a review on the concept of contrast in irony see Canestrari \& Bianchi 2018). An analysis of the conversational aspect of this interaction reveals that the therapist initially does not recognize the attempt at humour (e.g. line 9: "No") and he indicates disagreement (Hay 2001).The client's subsequent laughter (line 10) emphasizes the humour in line 8 and functions as an invitation to join in the laughter, indicating that the client is willing to recognize the attempt at humour (Jefferson 1979). The therapist's subsequent laughter in line 11 shows that he has understood the client's intention to be amusing and represents his support (Hay 2001) and alignment with the client. After this shared laughter (Jefferson 1979), the client continues the conversation using a jocular tone and asks for confirmation (12: "is that so?"). In lines 13 and 14 the therapist continues his explanation of the subject at hand, thereby restoring the metaphorical level and the serious tone of the conversation. As this extract shows, humour may serve as a coping strategy in a stressful situation (e.g. a panic attack). The client parodies the therapist using the same words while at the same time joking about the stressful situation she finds herself in.

\subsection{The use of humour by clients}

The following four examples illustrate the use of four different types of humour initiated by psychotherapists and show how clients modulate their appreciation and support for the humour. All of the cases analysed demonstrate that the therapists initiate humour in response to some interactional difficulty. This does not, however, lead to an extended sequence involving humour.

\subsubsection{Humour initiated by the therapist: rhetorical humour}

The following two transcripts both relate to a first encounter interview with a 44-year-old client who had suffered several episodes of panic attacks over the previous year. She had requested a consultation at her local Mental Health Centre and the therapist is investigating whether the client has previously met with other therapists, such as a psychologist or a psychiatrist. 


\section{Excerpt 4}

$1 \mathrm{~T}$ : Si è già rivolta a qualche psicologo, psichiatra:?

Have you already seen a psychologist, a psychiatrist?

$2 \mathrm{C}$ : No, da: (.) un neurologo, da due neurologi veramente. No, : (.) a neurologist, two neurologists actually.

3

1.0

1.0

$4 \mathrm{~T}: \quad$ Quando?

When?

$5 \quad 3.0$

3.0

$\rightarrow 6 \mathrm{~T}: \quad$ Bella domanda eh?

Good question, eh?

$7 \mathrm{C}$ : $\quad$ hh aha sì(2.0) il primo nel 2004.

hh hah yes (2.0) the first in 2004.

In response to the therapist's question (line 1), the client replies that she has seen two neurologists (line 2) and, after a pause of one second, the therapist then asks her when that happened (line 4). She does not answer and, after a long pause lasting three seconds, the therapist asks a rhetorical question with an ironic function (Gibbs 2000; Recchia et al. 2010) (line 6: "good question eh?"). In the following conversational turn, the client laughs, shows agreement (7: yes) and, after a two-second pause, she replies with a serious tone. It has been shown that rhetorical questions with an ironic meaning have the pragmatic function of being humorous rather than critical (Gibbs 1986) as is the case in this excerpt. In fact, it is ironic in that it diverges from the situation it refers to (i.e. the fact that it is not a good question since the client is unable to reply to it quickly) and in this case the therapist adopts the strategy of pretence (Clark \& Gerrig 1984). Its humorous function pivots on the opposition between the two scripts alluded to (i.e. it is a good question) and the referent situation (i.e. it is not a good question). Moreover, here, the therapist's intervention can be seen as having the function of rhetorical humour since its aim is to gain the support of the client by identifying himself (i.e. the communicator) with her (i.e. his audience), thereby enhancing his own credibility in her eyes (Gruner 2011). The therapist, having understood that the client is finding it difficult to remember, tries to put her at her ease and release tension by means of humour aimed at making his audience (the client) feel that she is in a more symmetric relationship with the speaker (the therapist) (Bordan \& Goldin 1999). In this way, the use of humour on the part of the therapist allows the client to 'bleed out' the anxiety and tension she is experiencing (Altman 2006).

\subsubsection{Humour initiated by the therapist: surreal irony}

In the following fragment (taken from the same consultation as that discussed in the previous excerpt, involving a 44-year-old client suffering from panic attacks), the therapist is investigating how the client has travelled to the office since she does not have a driving license.

\section{Excerpt 5}

$1 \mathrm{~T}$ : Quindi Angelina se lei, e::-come è venuta qui oggi, innanzitutto? So Angelina if you, and ::- how did you come here today, first of all?

$2 \mathrm{C}$ : $\quad$ Mi ha accompagnato.

He brought me. 
$3 \mathrm{~T}$ : Ah, ok. (.) Beh, eh: quindi le dà(.) però, disponibilità?

Ah, ok. (.) Well, eh: so he is(.) actually, helpful?

$4 \mathrm{C}$ : Beh, non tanta: infatti ha detto:: £questa è l'ultima volta£

$4 \quad$ Well, not so much: in fact he said $: \because £$ this is the last time£

$5 \mathrm{~T}: \quad$ ah!

$a h !$

$6 \mathrm{C}$ : $\quad$ £che ti ci porto£

fthat I'll bring you here£

$7 \mathrm{~T}$ : beh, calcolando che è il nostro primo incontro:

well, taking into consideration that it is our first encounter:

$8 \mathrm{C}$ : ahahah

hahhah

$\rightarrow 9 \mathrm{~T}: \quad$ Dovrei essere un[mago per farle] passare gli attacchi di panico

I would be a [magician to ] if I managed to make your panic attacks go away

$\rightarrow 10 \quad$ in:: $>$ una seduta $<$

$$
\text { in::>one session }<
$$

$11 \mathrm{C}: \quad$ [ahahah aha]

[hahhah hah]

12 T: Purtroppo(.) Ho paura che non ce la facciamo!

Unfortunately (.) I'm afraid we can't do that!

$13 \mathrm{C}$ : $\quad$ hh £lo so£ no vabbè tanto poi: se non mi vuole accompagnare lui:

hh £I know£ no well ok then: if he doesn't want to bring me:

$14 \mathrm{~T}$ : Però, abita qui a Milano lei?

But, you live here in Milan, don't you?

15 C: No, a Pavia.

No, in Pavia.

$16 \mathrm{~T}$ : Ah, ok. Ehm::: (.) no, che poi questo qui è un aspetto di cui::

Ah ok. Ehm .:. (.) no, then this is an issue that :.

17 dovremo parlare ed affrontare.

we need to talk about and discuss.

In the first part of this excerpt, the therapist and the client both contribute to the construction of the conversation. In line 2, when asked how she got to the clinic, she replies that she was brought by her partner who she had referred to in a previous part of the conversation (not reported here). The psychotherapist then asks a question about the helpfulness of the client's partner (line 3). She reports that the partner is not particularly helpful (4: "Well, not so much in fact he said") and then, using a jocular tone, relays what he said her before they arrived at the office (4: "this is the last time"; 6: "that I'll bring you here"). In the following conversational turn, the therapist points out that it is their first encounter (7: "Well, taking into consideration that it is our first encounter") and the client laughs. The therapist makes an intervention including surreal irony (Kapogianni 2011) (lines 9-10: "I would be a magician if I managed to make your panic attacks go away in one session") and the client aligns herself with the humorous frame of the conversation by laughing (line 11). The therapist goes on to inform the client that it would be impossible to achieve any results if there were no subsequent encounters. He makes a comment which is halfway between politeness and ironic understatement ("I'm afraid that" in line 12). In the next conversational turn the client takes a breath, then laughs, and, using a jocular tone, confirms that she has understood the situation.

This excerpt shows how the therapist makes use of humour involving surrealism in order to convey criticism of the target statement (Kapogianni 2014), specifically, the necessity to have more than one therapeutic session. The client's laughter in line 11 shows alignment with 
the humorous utterance pronounced by the therapist, allowing her to 'bleed out' her anxiety about the situation she is experiencing (Freud 1960). Moreover, since the client is willing to overcome her disease, we assume that she is facing a delicate issue related to the reason why she has asked for a therapeutic consultation, and this is also signalled by her use of a jocular tone (Haakana 2010) throughout the interaction.

\subsubsection{Humour initiated by the therapist: role shifting}

In this excerpt, the therapist is speaking to another female client (aged 54). She suffers from panic attacks and has asked her local Mental Health Centre for a consultation. She is nervous and confused and is also terrified of experiencing further panic attacks. In this extract, the therapist is giving her information about what can happen during an attack in order to help her understand her condition better.

\section{Excerpt 6}

$1 \mathrm{~T}$ : nel senso che un attacco di panico(.) ha un::a durata limitata, in the sense that a panic attack (.) has a :: limited duration,

2 sebbene possa sembrare (.3) uhm, tanto più tempo, con i sintomi although it may seem (.3) um, much longer, because of the symptoms

3 diciamo caratteristici dell'attivazione dell'ansia-quindi which are, let's say, particular to the activation of anxiety-so

4 come le dicevo(.) ehm:: visione sfocata, as I told you(.) ehm :: blurred vision,

5 tremore(.) ansia, senso di morire, e::: sudorazione(.2) trembling(.) anxiety, a feeling of dying, and $: .$. sweating (.2)

6 costrizione allo stomaco-quindi stomaco chiuso, Your stomach in a knot- then your stomach closed up,

$7 \quad$ [nodo alla gola: sono tutte] (.) [getting choked up: they are all](.)

$8 \mathrm{C}: \quad$ [e bravo (.) hehheh:= ] [ hey you're good (.) hehheh:=]

$\rightarrow 9 \mathrm{~T}$ : Ho studiato, sì grazie.

I've studied, yes thank you.

$10 \mathrm{C}:$ [uhuhuh]

[huhhuh]

$11 \mathrm{~T}$ : [eheheh] giramenti di testa, e via dicendo. [hehheh] dizziness, and so on.

The therapist is educating the client about her condition in order to improve her awareness of her symptoms (1-7). The client, in line 8, anticipates the upcoming point of transition relevance in the therapist's conversational turn by overlapping it with a positive comment related to the therapist accompanied by laughter (line 8). In the next conversational turn, the therapist makes a humorous comment with reference to his knowledge of the symptomatology of panic attacks (9: "I've studied, yes thank you"). Specifically, in this case, a shift between two scripts has happened: from that of "psychotherapist" (i.e. an expert who has completed a training program in the field of psychotherapy) to "student" (i.e. a non-expert still involved in a training program). This opposition leads to a further complementary role shifting in which the client becomes a teacher; the asymmetry of roles between the two interlocutors is maintained but inverted. The client recognizes the attempt at humour by laughing immediately, which is typical in cases where the humour is appreciated (Norrick 2003) and supported (Hay 
2001). After that, the therapist aligns himself with the client and laughs (line 11). Finally, in the same turn, he continues to speak until the point of transitional relevance occurs. The fact that the therapist shares the client's laughter in line 11 may signal his desire to put a stop to the "fun frame" and recover the serious theme (Holt 2010), which is in fact subsequently restored.

\subsubsection{Humour initiated by the therapist: humour relating to register}

This extract was taken from an interview with a male client, aged 32, who requested a consultation after experiencing a panic attack. In this excerpt, the therapist is investigating what happened immediately before the client suffered from his first episode in order to learn more about the situation.

\section{Excerpt 7}

$1 \mathrm{~T}$ : Ok, allora (.) quindi (.)se ho capito bene(.) lei era in macchina

$2 \quad$ Ok, then (.) So (.) If I have understood

going to your (.1) relatives?

$3 \mathrm{C}$ : No. Ero già arrivato. Ero:: andato a trovarli due giorni::

No. I had already arrived. I went :: to see them for two days :

$4 \quad$ e la sera sono stato a cena con questi amici qui: and in the evening I had dinner with some friends of mine:

5 e detto $\uparrow$ vabbeh:: $=\uparrow$

$\rightarrow 6 \mathrm{~T}: \quad$ 'fatto serata!:= 'a night out on the town!:=

$7 \mathrm{C}$ : $\quad$ fatto $\uparrow$ sera-serata! $\uparrow . h h h$ eh a night out $\uparrow$ on the town! $\uparrow$. hhh he

8 T: $\quad$ Sì sì, no Yeah, yeah, no

$9 \mathrm{C}$ : e::: e poi è successo dai questa cosa qui. Dopo mi hanno:: and $: \because$ and then this happened. Later they::

10 mi han: mandato- mi hanno fat::to, $>$ non lo so $<=$ Sent me- they did::> I do not know $<=$

$11 \mathrm{~T}$ : l'elettrocardiogramma. an electrocardiogram.

$12 \mathrm{C}$ : l'elettrocardiogramma. Valutato quella situazione lì. an electrocardiogram. So the situation was assessed.

In this excerpt, the therapist sums up what the client said previously in order to make sure that he has understood correctly. He then asks a question referring to where the client was going the night before suffering from a panic attack with a view to discovering what triggered the attack (lines 1-2). The client disagrees with the hypothesis of the therapist and corrects him (3: "No. I had already arrived. I went- to see them for two days"). In the following conversational turn, the client continues to explain what happened the evening before the panic attack (line 4: "and in the evening I had dinner with some friends of mine"), then (line 5) after a brief pause, he uses a high-pitched tone of voice and pronounces the words "oh well" prolonging the final sound. It can be hypothesized that he was thinking about something upsetting and was realizing that he would just have to deal with it. The therapist makes an interpolation using juvenile slang (6: "a night out on the town!") which provokes a shift from a formal to an informal register, typical of register humour (Attardo 1994). He uses the type of everyday 
language typical of speech between friends and young people. This is clearly very far from the type of speech used in a psychotherapy session in an institutional setting. The client indicates his appreciation by repeating the line (Norrick 1993) and laughing in line 7 . The therapist then restores a serious, formal register in line 8 ("Yes yes, no"), which is mirrored by the client (line 9).

According to Norrick and Spitz (2010), the therapist's comment may be interpreted as humour both at a local level (i.e. slang used in an institutional setting) and at a more global level (i.e. the therapist has understood what the client did the night before) (Norrick \& Spitz 2010). Starting from the assertion that different types of verbal humour apply to the cognitive mechanism involving the disjunction of different linguistic levels (Gîfu 2014), this example can be categorized as a disjunction of stylistic contexts which produces an opposition between juxtaposed registers. The aim of the humorous comment made by the therapist is to create a more relaxing atmosphere. The hope is that the client will overcome his resistance and open up sufficiently to be able to speak about what he was doing before the attack.

\section{Discussion}

The aim of this study was to investigate the presence and functions of humour in a corpus of first encounter Cognitive Therapy sessions in order to gain a better understanding of this subject. Overall, the results show that humour initiated by both clients and therapists is an important therapeutic resource. Although some consider that the use of humour in an early session is not generally to be recommended as the relationship has not yet developed and humorous comments may be misunderstood (Pierce 1994), this study shows how there are many occasions on which humour can be present and that it may lead to different outcomes.

In cases when it is the client who initiates humour, we found three possible outcomes: a) if the therapist does not acknowledge the humorous comment, the client laughs in order to make it clear that the intervention is intended to be humorous, and then the therapist aligns; $b$ ) the therapist quickly recognizes that the comment is meant to be humorous and laughs and c) the therapist does not align himself with the humorous intervention and continues to speak seriously. In a first encounter session, clients may initiate humour (usually associated with nervous laughter) to serve several purposes, with one of most common being to reduce emotional distress. In fact, humour is an adaptive and mature defence mechanism which helps people to gain distance from painful events and memories (Vaillant 2000). Clients may also use derogatory humour as a vehicle for expressions of frustration and derision toward the psychotherapist/psychiatrist (excerpt 1). Given the social status of physicians (which includes the power arising from their knowledge), humour may represent a possible coping mechanism for clients to deal with frustrating or depressing situations (Wear et al. 2006). People can sometimes use humour to relieve stress (excerpt 2): a less serious approach may facilitate a better understanding of their problems, offering insights into difficult issues (Meyer 2000). Finally, humour can serve psychological coping functions (excerpt 3): the client parodies what the therapist says, thereby attempting to cope with the awkwardness relating to the paradox of the expected outcome. This comprises any type of humour used to deal with a problem arising in the course of the conversation (Hay 2001). In these cases, focusing on laughter, humour and the issues stimulating it may be a useful tool for the therapist in terms of helping him/her to understand the client (Dionigi \& Canestrari 2018).

In a different way, when it was the therapist who made a humorous comment, the clients always laughed, signalling that they had understood that the therapist was trying to be humorous. Interestingly, the humour introduced by the therapists can be categorized into four different forms: rhetorical humour (excerpt 4), humour relating to a surrealistic meaning 
(excerpt 5), role shift (excerpt 6) and humour relating to register (excerpt 7). As in other studies (Haakana 2010), it is more likely that a client will laugh after a humorous comment made by a therapist than the other way around. However, the results of this study show that humour initiated by the therapists arose in response to some interactional difficulty and did not lead to an extended sequence involving humour (Buttny 2001). In these cases, humour offered an alternative way to proceed, with a view to improving the relationship between the therapist and the client, enabling both of them to go on with the conversation while also making it possible for the therapy to continue under a different guise. Nevertheless, due to the fact that there are several ways in which humour can be used in therapy (e.g. hyperbole, repetition or extension of prior humour, rhetorical humour, irony, a smiling voice) psychotherapists should make sure that any attempt at humour is appropriate to the moment, to the client's personality and to the issues being discussed (Sultanoff 2013). Sharing humorous comments and laughing together may promote feelings of intimacy and friendliness and facilitate the client's trust in the therapist, but there is also a risk of detrimental effects if the humour is misunderstood, used to belittle, laugh at, or mimic the client (Pierce 1994). For this reason, it might be useful for therapists to be trained to improve their sense of humour and integrate humour into therapy, while at the same time paying attention to personal factors such as individual proclivities for humorous repartee, the client's mentalizing capacity, and an authentic interest in adding humour to the session (Valentine \& Gabbard 2014).

There are some limitations to this research. Firstly, since there is a close relationship between individual personalities and appreciation of specific stimuli which are humorous and/or entertaining (Ruch 1994), it would be helpful to study this relationship within a psychotherapeutic setting. Secondly, nonverbal aspects (e.g. the presence or absence of smiling) were not investigated. Thirdly, the data studied are from first encounter psychotherapy sessions: further studies would be useful in order to evaluate the presence and functions of humorous utterances at other stages of the treatment. In this way, it would be possible to determine whether clients tend to respond positively to humorous comments made by therapists even when the relationship between them has developed, and to investigate the different functions that this type of humour may fulfil. Finally, this study focuses on a specific approach to psychotherapy (Cognitive Therapy): it would also be useful to verify the presence of humour in other types of therapy (e.g. humanistic therapy, psychoanalysis and psychodynamic therapies, etc.). Despite these limitations, this research has several implications for research and therapeutic practice since most of the claims made regarding the potential benefits and damage resulting from the use of humour in psychotherapy are based on personal experiences and anecdotal evidence. In the last decade, an ever-increasing number of studies have emerged, and a number of them are based on Conversational Analysis (e.g. Buttny 2001; Dionigi \& Canestrari 2018; Meyer 2000). In this way, there are clear examples of what happens during therapy sessions and what kind of humour is involved. The results of this study may help psychotherapists to gain a better understanding of the potential benefits of using humour during their sessions, both when initiated by themselves and by their clients.

\section{Appendix}

Transcription model employed in this paper:

? ascending tone

. descending tone

(.) brief pause

(0.2) a number inside brackets denotes a timed pause

hh exhale 


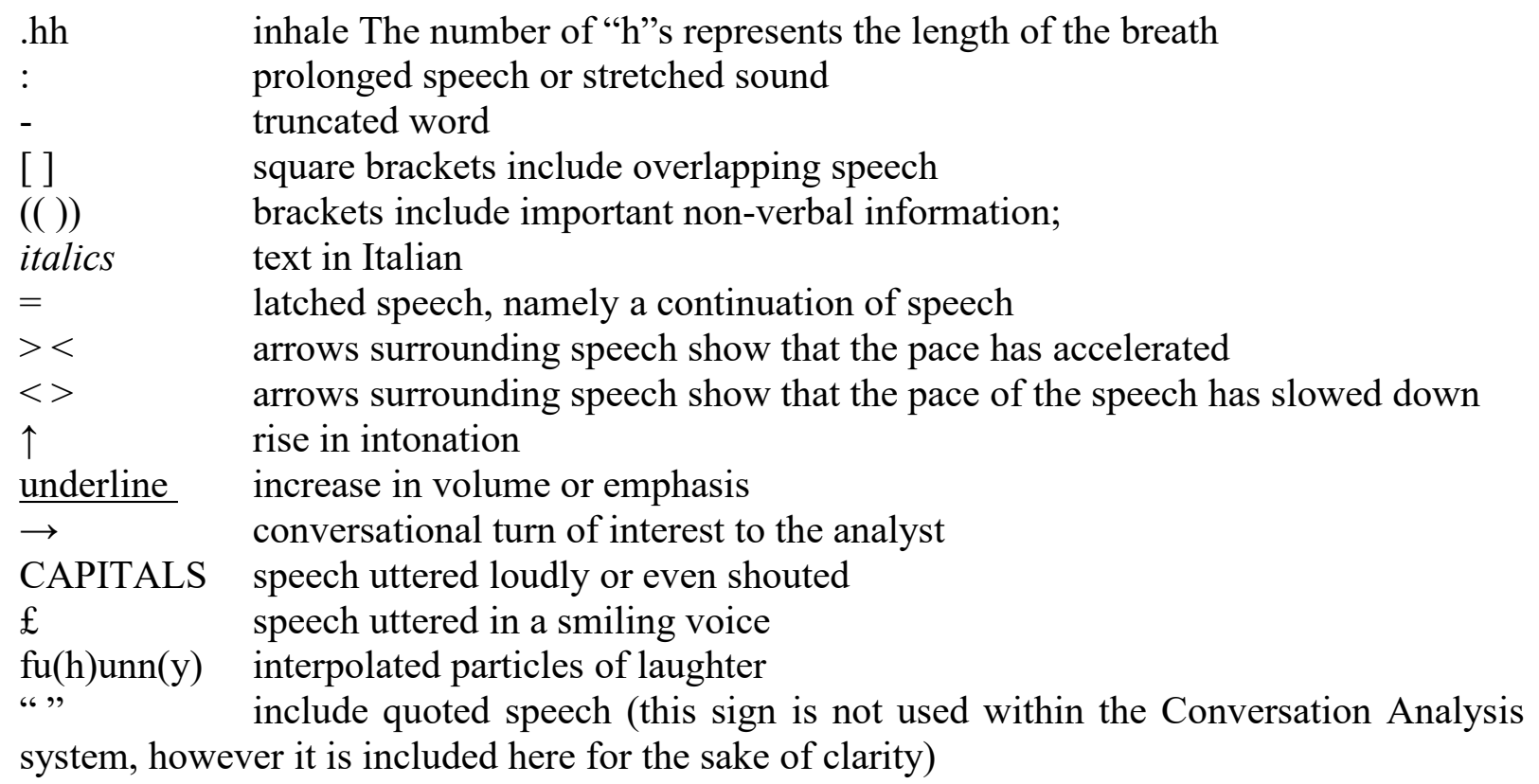

\section{References}

Allport, G. W. (1961). Pattern and Growth in Personality. New York: Holt, Rinehart and Winston.

Altman, N. (2006). 'And now for something completely different: Humor in psychoanalysis commentary on paper by Joseph Newirth'. Psychoanalytic Dialogues 16 (5), pp. 573-577.

Attardo, S. (1994). Linguistic Theories of Humor. Berlin: Mouton de Gruyter.

Attardo, S. (1997). 'The semantic foundations of cognitive theories of humor'. Humor: International Journal of Humor Research 10 (4), pp. 395-420.

Attardo, S. (2017). 'The General Theory of Verbal Humor', in Attardo, S. (ed.), The Routledge Handbook of Language and Humor, London: Routledge, pp. 126-142.

Attardo, S. \& Raskin, V. (1991). 'Script theory revis(it)ed: joke similarity and joke representation model'. Humor: International Journal of Humor Research 4 (3-4), pp. $293-$ 348.

Barbosa, E., Amendoeira, M., Ferreira, T., Teixeira, A.S., Pinto-Gouveia, J. \& Salgado, J. (2017). 'Immersion and distancing across the therapeutic process: relationship to symptoms and emotional arousal'. Research in Psychotherapy: Psychopathology, Process and Outcome 20 (2), pp. 110-121.

Bennett, H.J. (2003). 'Humor in medicine'. Southern Medical Journal - Birmingham Alabama 96 (12), pp. 1257-1261.

Bergen, B. \& Binsted, K. (2003). 'The cognitive linguistics of scalar humor', in Achard, M. \& Kemmer, S. (eds.). Language, Culture, and Mind, Stanford: CSLI Press, pp. 79-92.

Bianchi, I., Canestrari, C., Roncoroni, A.M., Burro, R., Branchini, E. \& Savardi, U. (2017). 'The effects of modulating contrast in verbal irony as a cue for giftedness'. Humor: International Journal of Humor Research 30 (4), pp. 383-415.

Bordan, T. \& Goldin, E. (1999). 'The use of humor in counseling: The laughing cure'. Journal of Counseling and Development 77 (4), pp. 405-410.

Buttny, R. (2001). 'Therapeutic humor in retelling the clients' tellings'. Text 21 (3), pp. 303326.

Canestrari, C. (2010). 'Meta-communicative signals and humorous verbal interchanges: a case study'. Humor: International Journal of Humor Research 23 (3), pp. 327-349. 
Canestrari, C. \& Bianchi, I. (2018). 'Perceptual opposites and the modulation of contrast in irony', Review of Cognitive Linguistics 16, pp. 48-71.

Canestrari, C., Branchini, E., Bianchi, I., Savardi, U. \& Burro, R. (2018). 'Pleasures of the mind: What makes jokes and insight problems enjoyable'. Frontiers in Psychology 8: 2297, pp. 1-21. doi: 10.3389/fpsyg.2017.02297

Canestrari, C., Dionigi, A. \& Zuczkowski A. (2014), 'Humor understanding and knowledge', Language and Dialogue 4 (2), pp. 261-283.

Cannon, W. (1932). Wisdom of the Body. New York: Norton \& Co.

Clark, H.H. \& Gerrig, R.J. (1984). 'On the pretense theory of irony'. Journal of Experimental Psychology: General 113 (1), pp. 121-126.

Corey, G. (2005) 'Gestalt theory', in Gebo, L. \& Gesicki, S. (eds.), Theory and Practice of Counseling and Psychotherapy, Belmont, CA: Brooks/Cole, pp. 192-223.

Dionigi, A. \& Canestrari, C. (2016). 'Clowning in health care settings: The point of view of adults'. Europe's Journal of Psychology 12 (3), pp. 473-488.

Dionigi, A. \& Canestrari, C. (2018) 'The role of laughter in cognitive-behavioral therapy: case studies'. Discourse Studies 20 (3), pp. 323-339.

Dynel, M. (2013). 'Irony from a neo-Gricean perspective: on untruthfulness and evaluative implicature'. Intercultural Pragmatics 10 (3), pp. 403-431.

Dziegielewski, S.F., Jacinto, G. A., Laudadio A. \& Legg-Rodriguez L. (2003). 'Humor: an essential communication tool in therapy. International Journal of Mental Health 32 (3), pp. 74-90.

Ellis, A. (1977). 'Fun as psychotherapy'. Rational Living 12 (1), pp. 2-6.

Forabosco, G. (1994). "'Seriality" and appreciation of jokes', Humor: International Journal of Humor Research 7 (4), pp. 351-375.

Freud, S. (1960). Jokes and Their Relation to the Unconscious. New York: Norton \& Co.

Fry Jr, W.F. \& Salameh, W.A. (1987). Handbook of Humor and Psychotherapy: Advances in the Clinical Use of Humor. Sarasota: Professional Resource Exchange, Inc.

Gibbs, R.W. (1986). 'On the psycholinguistics of sarcasm'. Journal of Experimental Psychology: General 115 (1), pp. 3-15.

Gibbs, R.W. (2000). 'Irony in talk among friends'. Metaphor and Symbolic Activity 15 (1-2), pp. 5-27.

Gîfu, D. (2014). 'Humor in the religious discourse: between paradoxism and neutrosophy', in Smarandache, F., \& Vlăduţescu, Ş. (eds.), Communication. Neutrosophic Routes, Columbus, Ohio: Education Publishing, pp. 88-104.

Grice, H.P. (1975). 'Logic and conversation', in Cole, P., \& Morgan, H. (eds.), Syntax and Semantics, Vol. 3, Speech Acts, New York: Academic Press, pp. 41-58.

Gupta, R., Chaspari, T., Georgiou, P.G., Atkins, D.C. \& Narayanan, S.S. (2014). 'Predicting client's inclination towards target behavior change in motivational interviewing and investigating the role of laughter'. Interspeech-2014, pp. 208-212.

Gruner, C. (2011). The Game of Humor: A Comprehensive Theory of Why We Laugh. New Brunswick NJ: Transaction Publishers.

Haakana, M. (2001). 'Laughter as a patient's resource: dealing with delicate aspects of medical interaction'. Text 21 (1/2), pp. 187-219.

Haakana, M. (2010). 'Laughter and smiling: notes on co-occurrences'. Journal of Pragmatics 42 (6), pp. 1499-1512.

Hay, J. (2001). 'The pragmatics of humor support'. Humor: International Journal of Humor Research 14 (1), pp. 55-82.

Holt, E. (2010). 'The last laugh: shared laughter and topic termination'. Journal of Pragmatics 42 (6), pp. 1513-1525. 
Jacobs, S. (1986). 'How to make an argument from example in discourse analysis', in Ellis, D.G. \& Donohue, W.A. (eds.), Contemporary Issues in Language and Discourse Processes, Hillsdale, NY: Lawrence Erlbaum, pp. 149-167.

Jefferson, G. (1979). 'A technique for inviting laughter and its subsequent acceptance declination', in Psathas, G. (ed.), Everyday Language: Studies in Ethnomethodology, New York: Irvington Publishers, pp. 79-96.

Kapogianni, E. (2011). 'Irony via "surrealism"', in Dynel, M. (ed.), The Pragmatics of Humour across Discourse Domains, Amsterdam/Philadelphia: John Benjamins Publishing, pp. 51-68.

Kapogianni, E. (2014). 'Differences in use and function of verbal irony between real and fictional discourse: (mis) interpretation and irony blindness'. Humor: International Journal of Humor Research 27 (4), pp. 597-618.

Kuhlman, T.L. (1984). Humor and Psychotherapy. Belmont, CA: Wadsworth Publishing Company.

Lynch, O.H. (2002). 'Humorous communication: finding a place for humor in communication research'. Communication Theory 12 (4), pp. 423-445.

Mahrer, A.R. \& Gervaize, P.A. (1984). 'An integrative review of strong laughter in psychotherapy: what it is and how it works'. Psychotherapy: Theory, Research, Practice, Training 21 (4), pp. 510-516.

Marci, C.D., Moran, E.K. \& Orr, S.P. (2004). 'Physiologic evidence for the interpersonal role of laughter during psychotherapy'. Journal of Nervous \& Mental Disease 192 (10), pp. 689-695.

Martin, R. (2007). The Psychology of Humor. An Integrative Approach. New York: Academic Press.

Meyer, J.C. (2000). 'Humor as a double-edged sword: four functions of humor in communication'. Communication Theory 10 (3), pp. 310-331.

Nelson, J. (2008). 'Laugh and the world laughs with you: an attachment perspective on the meaning of laughter in psychotherapy'. Clinical Social Work Journal 36 (1), pp. 41-49.

Norrick, N.R. (2003). 'Issues in conversational joking'. Journal of Pragmatics 35 (9), pp. 1333-1359.

Norrick, N.R. (1993). Conversational Joking: Humor in Everyday Talk. Bloomington, IN: Indiana University Press.

Norrick, N.R. \& Spitz, A. (2010). 'The interplay of humor and conflict in conversation and scripted humorous performance'. Humor: International Journal of Humor Research 23 (1), pp. 83-111.

Pierce, R. (1994). 'Use and abuse of laughter in psychotherapy', in Strean, H. (ed.), The Use of Humor in Psychotherapy, Northvale, NJ: Jason Aronson, pp. 105-111.

Pomerantz, A. (1984). 'Agreeing and disagreeing with assessments: Some features of preferred/dispreferred turn shapes', in Atkinson, J.M. and Heritage, J. (eds.), Structures of Social Action: Studies in Conversation Analysis, Cambridge: Cambridge University Press, pp. 57-101.

Provine, R.R. (2004). 'Laughing, tickling, and the evolution of speech and self'. Current Directions in Psychological Science 13 (6), pp. 215-218.

Pomeroy, L. \& Weatherall, A. (2014). 'Responding to client laughter as therapeutic actions in practice'. Qualitative Research in Psychology 11, pp. 420-434.

Raskin, V. (1985). Semantic Mechanism of Humor. Dordrecht/Boston/Lancaster: D. Reidel.

Raskin, V. \& Attardo, S. (1994). 'Non-literalness and non-bona-fide in language: an approach to formal and computational treatments of humor'. Pragmatics \& Cognition 2 (1), pp. 3169. 
Recchia, H.E., Howe, N., Ross, S.H., \& Alexander, S. (2010). 'Children's understanding and production of verbal irony in family conversations'. British Journal of Developmental Psychology 28, pp. 255-274.

Rockwell, P. (2000). 'Lower, slower, louder: vocal cues of sarcasm'. Journal of Psycholinguistic Research 29 (5), pp. 483-495.

Ruch, W. (1994). 'Temperament, Eysenck's PEN system, and humor-related traits'. Humor: International Journal of Humor Research 7 (3), pp. 209-244.

Schaffer, R. (1982). 'Are there consistent vocal clues for irony', in Masek, C.S., Hendrick, R.A., \& Miller, M.F. (eds.), Papers from the Parasession on Language and Behavior, Chicago: Chicago Linguistic Society, pp. 204-210.

Schegloff, E.A. (2007). Sequence Organisation in Interaction. Cambridge: Cambridge University Press.

Sperber, D., \& Wilson, D. (1981). 'Irony and the use-mention distinction, in Cole, P. (ed.), Radical Pragmatics, New York: Academic Press, pp. 295-318.

Strean, H.S. (ed.) (1994). The Use of Humor in Psychotherapy. Northvale, NJ: Jason Aronson.

Sultanoff, S.M. (2013). 'Integrating humor into psychotherapy: research, theory, and the necessary conditions for the presence of therapeutic humor in helping relationships'. The Humanistic Psychologist 41 (4), pp. 388-399.

Vaillant, G.E. (2000). 'Adaptive mental mechanism: their role in a positive psychology'. American Psychologist 55 (1), pp. 89-98.

Valentine, L. \& Gabbard, G.O. (2014). 'Can the use of humor in psychotherapy be taught?'. Academic Psychiatry 38 (1), pp. 75-81.

Ventis, W.L., Higbee, G., \& Murdock, S.A. (2001). 'Using humor in systematic desensitization to reduce fear'. Journal of General Psychology 128, pp. 241-253.

Voutilainen, L. \& Peräkylä, A. (2016). 'Interactional practices of psychotherapy', in O'Reily, M. \& Lester, J.N. (eds.), The Palgrave Handbook of Adult Mental Health, London: Palgrave Macmillan, pp. 540-557.

Wear, D., Aultman, J.M., Varley, J.D., \& Zarconi, J. (2006). 'Making fun of patients: medical students' perceptions and use of derogatory and cynical humor in clinical settings'. Academic Medicine 81, pp. 454-462. 